\title{
English Language Learning In the Digital Age: Case Study at the Southeast European University
}

\author{
Kujtim Ramadani \\ Southeast European University / the Language Center
}

\begin{abstract}
With the emergence of Information and Instructional Technologies and their influence on teaching and learning it becomes a must to equip faculty members and students with the necessary skills to handle these developments and utilize their benefits in teaching and learning. The swift development of new technologies and their universal application in education requires innovative methods and approaches in teaching and learning a language in the digital age. This paper provides an overview of how technology has evolved in time and how it contributes to language communication, alongside political, economic and social lines in the Republic of Macedonia in general and at the Southeast European University in particular. In this respect, we will also focus on the latest trends in the area of language learning in the digital age and the efforts that our university is making in order to keep in step with them, especially through several of its units that have been specifically established with this mission in mind, such as the e-learning center and the language center.
\end{abstract}

Keywords: digitalization; e-learning; information technology; internationalization; skills 